\title{
COVID-19, Health Systems Corruption, Economic Priorities and Poverty: The Case of South Africa
}

\author{
Evangelos A. Mantzaris \\ ORCiD ID: https://orcid.org/0000-0003-0490-6953
}

\section{Pregala Pillay \\ ORCiD ID: https://orcid.org/0000-0002-2101-962X}

\begin{abstract}
The South African government has been hailed internationally for its strategies and tactics in facing the challenges of COVID-19, at least during the initial stages of the pandemic. However, as time has passed, several questions have been raised on a wide range of issues due to key realities of social and economic policies, the responsibilities, capabilities and relationships of state layers and institutions, and the measures undertaken. It became evident after the first week following the lockdown in South Africa, that the deep consequences of chronic corruption at all levels and sectors, especially water and public health, had serious negative repercussions for the poorest of the poor and the marginalised communities. The actual repercussions have not been calculated yet, as priorities have changed significantly. Questions regarding the availability of 10\% of the country's GDP (R500 billion), their beneficiaries, and the R130 billion made available through budget reprioritisation have not been answered, with the exception of the hundreds of millions attached to the remuneration of the 200 Cuban medical doctors, while the continuous reports on open and hidden corruption perpetrated by amongst others politicians, administrators, drug dealers, underground illegal operators including fake cigarette producers, and police personnel, continue unabated. Recent research has shown that the shortages of food amongst the poor begun a week before the lockdown and worsened during it. It took almost six weeks
\end{abstract}


from the start of the lockdown on the $26^{\text {th }}$ of March to the topping up of the child support grant by R300 on 6 May, to stop hunger amongst South Africa's poor communities. The article aspires to research, analyse and dissect the direct and indirect effects of corruption and its consequences and repercussions on the impact of COVID-19 to the most vulnerable communities in the country. It deals with corruption, its types, monitoring and assessment, effectiveness and efficiency of the security and enforcement agencies and their operations, as well as their repercussions for the poorest of the poor. Eight telephonic interviews with state officials throughout the country were conducted, four civil society groups directly involved in community and benevolent work participated through an open-ended questionnaire which was administered, using the judgemental sampling frame. All existing national and provincial government documents relating to the period as well as media articles have been searched, classified, and analysed through the separation and categorisation of themes (content analysis). The common patterns, themes, categories, and trends were dissected. The article covered a forgotten aspect of the period as its impact is not only sociological/criminological/historical but also contributes to understanding the existing gaps in government's social policy for the poor. The research aspires to make an original contribution to the 'hidden history' in the COVID-19 conundrum.

Keywords: COVID-19, Corruption, thematic analysis, government sectors, social policy

\section{Introduction}

When a reality like coronavirus hits humanity and life throughout the world, it re-discovers the value of its mere existence. The vast majority of people suffer and politicians show their real face, in most cases occasionally, and their success or failure follows them till their last breath. In South Africa as everywhere else, as time goes by, myriads of questions arise as the Covid-19 death toll increases.

From the Spanish flu to Ebola, the success or failure of response depends on the cooperation, coordination and synergy between state and society. When or if the state has the political will, financial capability, solid governance, continental and international cooperation, and the support of the 
majority of the population, the possibilities for success increase. When corrupttion occurs, the whole society suffers, especially the poor, the marginalised and the vulnerable, and when a pandemic does hit, the existence of a solid and functional health infrastructure and service offers hope. Corruption has negative effects on all aspects and sectors of society, including health.

The article based on the qualitative interpretative paradigm, is an empirical effort aspiring to investigate and analyse the existing evidence connecting the present COVID-19 realities, and the direct and indirect relations between corruption, the existing health system and the poor and the marginalised in South African society.

\section{The Context}

On the $30^{\text {th }}$ of January 2020, the World Health Organisation (WHO) declared Coronavirus a 'public health emergency' and on the $11^{\text {th }}$ of March a 'global pandemic'. The fast spreading of the virus throughout the world was thoroughly publicised, and soon Africa and South Africa followed.

In South Africa, the country's Institute for Communicable Diseases (ICD) announced the first coronavirus patient on $5^{\text {th }}$ March 2020. The government, based on Section 27(2) of the Disaster Management Act of 2002, declared a State of National Disaster which was followed by a 21-day national lockdown that commenced on the $26^{\text {th }}$ March 2020. A new body named 'The National Coronavirus Command Council' was established in order to strategically deal with responses and immediate responses and mitigation to the virus. The initial plan against the virus was based on a strategy consisting of a risk adjustment strategy of 5 levels. Level 5 was eased on $1^{\text {st }}$ May 2020 to level 4 and on $1^{\text {st }}$ June, to level 3. On $2^{\text {nd }}$ June, levels 4 and 3 were declared invalid and unconstitutional by the country's High Court, a verdict that has been appealed.

\section{Design and Research Methodology}

To research and analyse the effects of corruption and its consequences and repercussions on the impact of COVID-19 to the most vulnerable communities in the country, the article is based on the utilisation of the qualitative paradigm founded on a reflective, content analysis approach. The article and its research method have their roots in the researchers' experience and writings associated 
with both the health sector and the poor and vulnerable throughout the years. A qualitative reflective approach and analysis focusses on the pandemic and corruption content and their effects on the poor and the marginalised. Eight telephonic interviews with state officials throughout the country and four civil society groups directly involved in community and benevolent work took place through an open-ended questionnaire. The judgemental sampling frame was utilised.

All existing national and provincial government documents relating to the period as well as media articles were searched, classified, and analysed through the separation and categorisation of themes (content analysis). All qualitative data was carefully gleaned through these two methods, and were scrutinised thoroughly. The conventional content analysis was followed in this article as the coding categories were derived from the text data. Anonymity and confidentiality were guaranteed to all interviewees.

\section{Corruption in the Health Sector Internationally and South Africa: A Brief Look}

Health care corruption internationally, and in South Africa has devastating effects on mortality, especially infant mortality, and life expectation in general. It takes a very wide variety of practices fluctuating from the 'simple ones' such as bribes, theft, absenteeism, to the more complicated such as supply chain and procurement 'third party collusion', misinformation, false purchases, illegal medicine distribution and faulty prescription (Vian 2008:87-88; Barr et al. 2009:226-227).

Several widely accepted research reports (World Health Organization 2000; World Health Organisation 2012:7 - 8; Greer et al. 2016:16 - 17) have identified the lack of serious planning, designing and implementation on the part of health leaderships especially in the public sector, as the key to the lack of effectiveness, efficiency, and good governance at all levels of the sector. This is because of the ever-changing environment and conditions that 'ultimately' could lead to corruption because of complexities evident throughout the world, especially in the developing countries. Such realities imply that governments need to build and develop capacities that will be instrumental in transforming operations, structures, systems, and processes in the healthcare terrain that is capable to produce public value for everyone, especially the vulnerable (Greer et al. 2016:17). 
It can be understood that such imperatives are even more necessary in the era of Coronavirus. This because as previous experiences have shown, such outbreaks lead to a serious expansion of corrupt practices, especially in terms of resource pressures, including fundamentals such as shortages in crucial human resources and specialised workforce (nurses and medical specialists), as well as poor access and shortages in protective clothing and medicines.

The International Federation of Red Cross and Red Crescent Societies (IFRC), which was in the forefront of the fight against the Ebola epidemic, exposed the millions of USA dollars lost in corruption during the 2012-2014 period (IFRC 2014). During the time of Ebola, corruption was evident in the mismanagement of foreign funds: staff salaries were misrepresented, food and pharmaceutical supplies were duplicated continuously and public servants were perpetually bribed, mainly for allowing people to escape from the quarantined zones (U4 BRIEF 2015).

The massive corruption in pharmaceuticals related to the swine flu outbreak and the Tamiflu affair showed the unlimited perversion of corrupt syndicates that convinced the whole world to survive the virus by spending over 18 billion USA dollars to stockpile this medication, which after serious scientific research that lasted years, was shown to be no more effective than paracetamol in treating swine flu due to safety and efficacy concerns (Cochrane 2014).

Such pandemics lead to massification problems for hospitals and clinics, meaning that both human, medical, nursing and infrastructure resources, including bedding, were limited. Medical and nursing staff face hourly struggles in the efforts to cope with pandemics such as COVID-19. Research in the Middle East and Africa has shown that such realities inevitably lead to bribes, especially in state establishments (Personal Interview 1, Professor of Medicine, Durban). This means that under the threat of a pandemic as serious as Coronavirus, health professionals at all levels are obliged to set their priorities on those who need it and those who accept bribes need to be punished as an example, given the expected frequency of such gestures from those willing to bribe in order to receive care.

It is widely accepted amongst senior and honest medical practitioners that in such circumstances, the most vulnerable are those who cannot bribe because although they deserve to be on the top of the list, they are positioned at the bottom by unscrupulous 'professionals'. This means that the important issue in all hospitals is that all waiting lists need to be transparent and open 
for inspection anytime (Personal Interview 2, NGO CFO, Durban).

A series of analyses of the existing levels of corrupt public health governance systems in South Africa pinpointed a wide variety of actions, relationships, structures, functions, and systems that suffer from the lack of policy, rules and regulations'; coordination in terms of organisational dictates; organisational deficiencies in key systems such as finance, risk management, internal audit, supply chain and procurement; loose and inadequate human resource systems; weak staff capacity leading to perpetration of corrupt practices; conflict of interest; nepotism and perpetual infighting between administrators and politicians. These are all factors leading to corrupt collusion practices with 'middlemen and women' (Pillay \& Mantzaris 2017: 58). Within the same context, in the attempt to present the first comprehensive Evidencebased Corruption Index in the public sector terrain in Africa, Mantzaris (2018) utilised the UNDP Oslo Governance Centre to construct an exact comprehensive categorisation of levels and specific acts of corruption. The approach was founded on an exhaustive scrutiny and categorisation of corrupt acts recorded and Section 9 institutions and government sources, content analysis of newspaper reports and personal interviews with politicians and senior administrators, as well as consultants who have direct and continuous involvement in such issues.

The corrupt cases recorded in the chosen provincial Health Department were theft, including medicine cell phones, cars, kitchen equipment and departmental property (289 or $31.1 \%$ ); absenteeism (196 or $21.1 \%$ ) fraud, including making use of government stamps to validate fraudulent birth certificates, misrepresenting educational qualifications etc. (100 or 10.8\%); absence without leave (56 or $6 \%$ ); insubordination (44 or $4.7 \%$ ); negligence (44 or $4.7 \%$ ); supply chain and procurement fraud (42 or $4.5 \%$ ); falsification of records for cash (bribery) (36 or 3.9\%); desertion of post (26 or $2.8 \%$ ) and misappropriation of departmental property $21(2.3 \%)$ (Mantzaris 2018:276).

\section{Coronavirus, the Poor and the Vulnerable}

South Africa's population according to the latest statistics was 58.780 .000 in mid-2019, dominated by the 18-34 youth group at 17. 840.000. The youth unemployment stood at $39,5 \%$ at the time, while $28.8 \%$ had completed tertiary education. The latest statistics associated with the 2015 Living Conditions 
Survey Report has indicated that 33, 4\% are considered poor on a multidimensional poverty scale. According to the latest poverty statistics, there were 35, 1 million adults (aged 18 years and older) in South Africa living in poverty in 2015. The number of females living below the poverty line according to the upper-bound poverty line was $49,9 \%$ as against $33,0 \%$ for males.

At the upper-bound poverty line, 53,7\% of non-poor children lived in neighbourhoods with safe play areas compared to $25.7 \%$ for poor children (Statistics South Africa 2019a). The Household Affordability Index produced by the Pietermaritzburg Economic Justice \& Dignity Group (2019) uncovered the truth of poor families struggle to make ends meet, who suffer from lack of proper nutrition that negatively affects children who face serious problems such as perpetual stunting. The index calculated the cost of foods in a poor household food basket at R3 009.65, while the median wage for black South African households was R3 000. The fact that transport and electricity costs increased substantially meant that poor households ended up spending at least $25 \%$ less on groceries.

Electricity increased by $13.07 \%$ and petrol by $8 \%$, meaning that transport expenses for the poor, the workers and the lower middle classes saw the taxi fares becoming more expensive. This meant that these social categories of people were left with R1 249.48 to secure all other essential household expenses as the cost of a basic family of four basket of nutritional food was R2 318.97 (Pietermaritzburg Economic Justice \& Dignity Group 2019).

The latest Statistics South Africa's General Household Survey released in 2019 showed that social grants were the second-most important source of income for households in the country after salaries. The findings indicated that $45.2 \%$ of households depend on the grants, while $64.8 \%$ of households receive salaries, remittances, pensions, and businesses. This means that more than one in five South Africans (more than 17 million) rely on state social welfare grants. It was expected that such social protection spending on social protection would increase from R193 billion this financial year to R224 billion in 2021(Statistics South Africa 2019b).

The situation of these social groups, predominantly black, has at least during the beginning of the pandemic not really changed substantially. This because families who, for example, receive a R420 child support grant, are $25 \%$ below the food poverty line of R561 per capita per month. Empirical research has shown that basic nutrition for a 10-13-year-old child costs $\mathrm{R}$ 568.41 per month (Pietermaritzburg Economic Justice \& Dignity Group 2019). 


\section{The Realities: Corruption, Health Systems, and the Poor}

Despite the hopeful start in the fight against COVID-19 in the first period of the lockdown, reaching a total number at 48,285 cases and 998 deaths, an increase of 46 per day by the 7 June created a new feeling of scepticism, pessimism, and despondency from the higher state echelons to the locked up closed spaza shop in Section L, Umlazi.

\section{TABLE 1}

Number of COVID -19 cases and deaths per province as of 7 June 2020

$\begin{array}{lll}\text { Province } & \text { Case Numbers } & \text { Deaths } \\ \text { Western Cape } & \mathbf{3 1 , 8 2 4} & 774 \\ \text { Eastern Cape } & \mathbf{5 , 9 7 4} & 101 \\ \text { Gauteng } & \mathbf{5 , 9 4 6} & 47 \\ \text { KwaZulu-Natal } & \mathbf{3 , 1 0 8} & 61 \\ \text { Free State } & \mathbf{3 6 1} & 9 \\ \text { Limpopo } & \mathbf{2 2 7} & 3 \\ \text { North West } & \mathbf{5 2 3} & 1 \\ \text { Mpumalanga } & \mathbf{1 8 9} & 1 \\ \text { Northern Cape } & \mathbf{1 1 4} & 1 \\ \text { Unknown } & \mathbf{1 9} & 0\end{array}$

Source: The Authors 
In fact, the data presented in Table 1 has shown that such a very noticeable growth in cases day by day indicated that the road ahead would be a massive new wave of coronavirus cases sooner or later. The existing national situation in terms of case numbers shows that the Western Cape is the province that has the highest number of recorded COVID-19 cases and deaths in the country, followed by the Eastern Cape with 5,974 cases and 101 deaths. Gauteng is third with 5,946 cases and 47 deaths. Senior medical academics and practitioners warned openly and publicly that although the Western Cape is at the time topping the death list, it was expected that both the Eastern Cape and Gauteng would be facing major waves of infections in the next few weeks (City Press 2020).

In his Presidential official letter, the President of South Africa, pinpointed his serious worries on the fast rise of the infections even though there was prior knowledge regarding the increase because of the existence of the projections via the various existing models. However, despite these facts, he felt strongly that the country could draw 'some comfort' from the understanding that the national lockdown had achieved the main objective which was the 'delaying (of) the spread of the virus', thus providing the state with enough time to prepare the country's health interventions and facilities for the forthcoming spike in infections that was expected (Presidency of South Africa 2020).

A 'social category' based analysis and scrutiny of realities outlined in detail to the researcher from a progressive non- governmental organisation in Cape Town pinpoints several realities. The classified 'hotspot areas' whose populations are expecting government to assist them financially at containing the spread of the virus, are to be found in areas such as the Johannesburg inner city, Soweto, Randburg and various districts around Ekurhuleni, all inhibited by poor, marginalised and predominantly black people. Similarly, in the Western Cape, the hotspot areas are situated in Tygerberg, Khayelitsha, Klipfontein, Cape Town South, and Mitchells Plain, also predominantly poor areas.

(Personal Interview 4, Senior Researcher, Labour and Geography, Western Cape). 
COVID-19, Health Systems Corruption, Economic Priorities and Poverty

Table 2: Number of Covid-19 Cases in the Western Cape

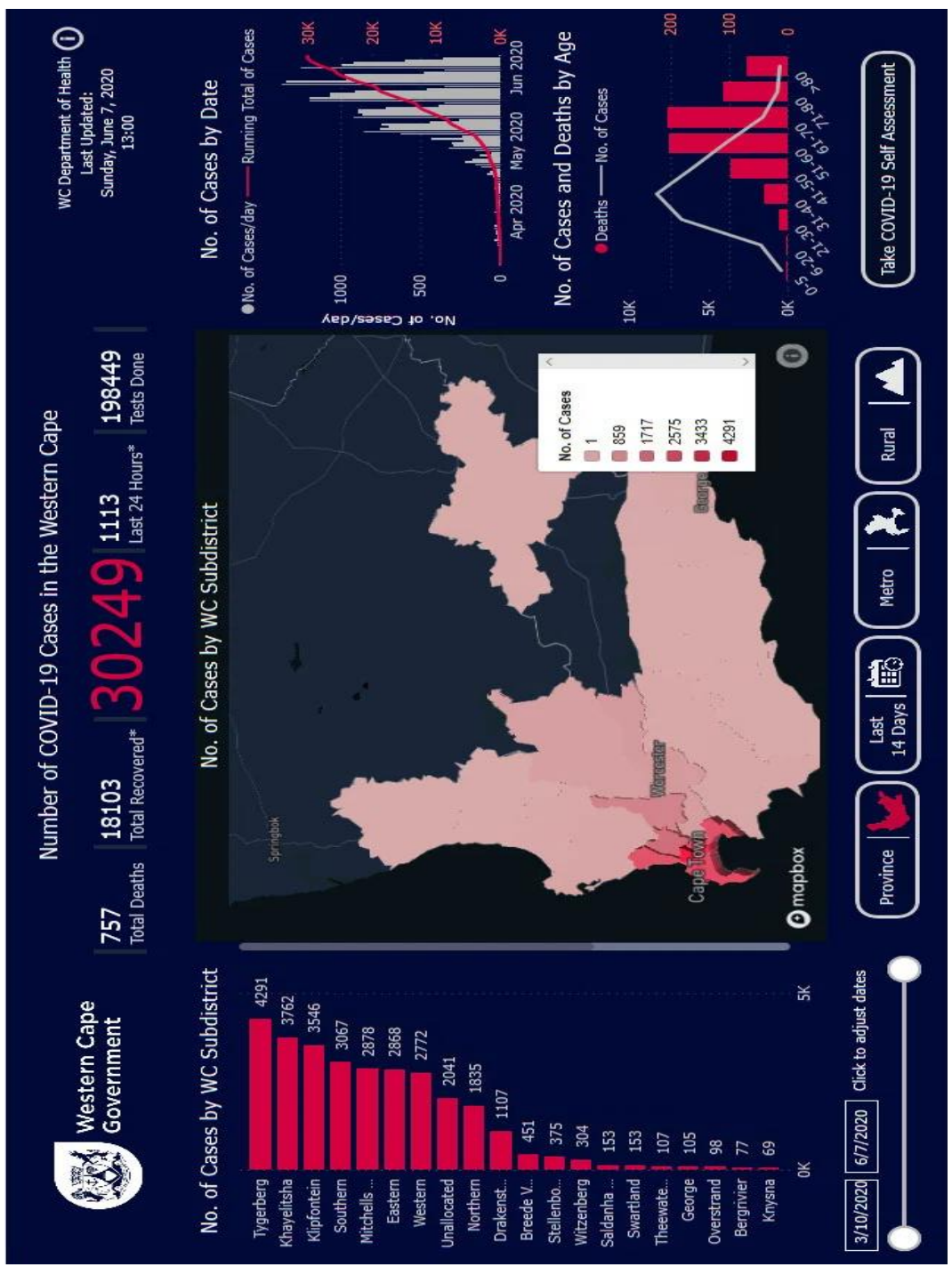

Also on 6 June 2020, This is what the Gauteng statistic District Breakdown situation was. 


\section{Table 3}

\begin{tabular}{|c|c|c|c|c|c|}
\hline District & $\begin{array}{l}\text { Total } \\
\text { District }\end{array}$ & $\begin{array}{l}\text { Total } \\
\text { Recoveries }\end{array}$ & Sub-District & $\begin{array}{l}\text { Total } \\
\text { Sub-District }\end{array}$ & $\begin{array}{l}\text { Recoveries } \\
\text { Sub-District }\end{array}$ \\
\hline \multirow{8}{*}{$\begin{array}{l}\text { City of } \\
\text { Johannesburs }\end{array}$} & \multirow{8}{*}{2732} & \multirow{8}{*}{1391} & $\begin{array}{l}\text { City of Johannesburg A: Diepsioot, Kya Sands, } \\
\text { Dainfern, Midrand, Lanseria, Fourways, Jvery Park. }\end{array}$ & 284 & 218 \\
\hline & & & $\begin{array}{l}\text { City of Johannesburg B: Randourg, Rosebanik, } \\
\text { Emmarentia, Greenside, Melville, Maytair, Northcirf, } \\
\text { Parktown, Parktown North }\end{array}$ & 403 & 191 \\
\hline & & & $\begin{array}{l}\text { City of Johannesburg C: Roodepoort, Constantia Kloof, } \\
\text { Northgate, Florida, Bram Fishersville }\end{array}$ & 266 & 122 \\
\hline & & & $\begin{array}{l}\text { City of Johannesburg D: Doomkiop, Soweto, } \\
\text { Dobsonville, Protes Gien }\end{array}$ & 452 & 180 \\
\hline & & & $\begin{array}{l}\text { City of Johannesburg E: Alexandrs, Wynberg. } \\
\text { Sandton. Orange Grove. Houghton }\end{array}$ & 472 & 303 \\
\hline & & & City of Johannesburg F: Inner City, Johannesburg South & 542 & 194 \\
\hline & & & $\begin{array}{l}\text { City of Johannesburg G: Orange Farm, Weilers Farm, } \\
\text { Ennerdale, Lenasia, Eldorado Park, Protea South }\end{array}$ & 176 & 99 \\
\hline & & & Unallocated & 137 & 84 \\
\hline \multirow{8}{*}{ City of Tshwwane } & \multirow{8}{*}{709} & \multirow{8}{*}{354} & $\begin{array}{l}\text { City of Tshwaane 1: Ga-Rankiwwa, Mabopane Winterveldt, } \\
\text { Soshanguve, Rosslyn, Karenpark, Wonderboom, Akasia, } \\
\text { Nina Park, Orchads, Amandasig. Thereza Park, Pretoria } \\
\text { North }\end{array}$ & 95 & 58 \\
\hline & & & $\begin{array}{l}\text { City of Tshwane 2i. Hammansikaal, Temba, Suurman, } \\
\text { Dilogye, Stinkwater, Ramotse, New Eesterus, } \\
\text { Kameeldrit, Pyramid/Rooiwal, Doornpoort, Kekana } \\
\text { Gardens, KekansStad, Marokolong, Randstown, Kanana }\end{array}$ & 41 & 15 \\
\hline & & & $\begin{array}{l}\text { City of Tshwwane 3: Asteridgeville, Laudium, Pretoria CBD, } \\
\text { Hercules, Danville. Ssulsville, Lotus, Pretoria West }\end{array}$ & 238 & 105 \\
\hline & & & 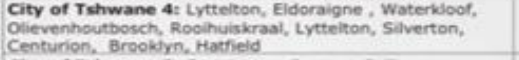 & 153 & 70 \\
\hline & & & $\begin{array}{l}\text { City of Tshwwane 5: East Lymne, Raveon, Cullinan, } \\
\text { Dewagensdrift, Refliwe, Silverton, Onverwache }\end{array}$ & 22 & 11 \\
\hline & & & $\begin{array}{l}\text { City of Tshwarne 6: Eesterus, Lethabong, Mamelodi, } \\
\text { Silverlakes, Garsfontein, Lynmwood, Queenswood, } \\
\text { Wilgers, Watloo, Equestria, Mooikioof, Brummeria }\end{array}$ & 118 & 76 \\
\hline & & & $\begin{array}{l}\text { City of Tshwwane 7: Ekangala, Sokhulumi, Dark } \\
\text { City, Zithobeni, Bronkhorstspruit, Kanana, } \\
\text { Rethabiseng }\end{array}$ & 19 & 12 \\
\hline & & & Unallocated & 23 & 7 \\
\hline \multirow{7}{*}{ City of Ekwrhulinni } & \multirow{7}{*}{1140} & \multirow{7}{*}{582} & $\begin{array}{l}\text { Ekurhuleni East 1: Etwatwa, Daveyton, Brakpan, } \\
\text { Tsakane }\end{array}$ & 84 & 56 \\
\hline & & & Ekurhuleni East 2: Springs, Kwa-Thema, Duduza, Nigel & 72 & 37 \\
\hline & & & $\begin{array}{l}\text { Ekurhuleni North 1: Birchileigh, Birchieigh North, } \\
\text { Bonaero Park, Orystal Park, Erin, Ethafeni, Kempton } \\
\text { Park, Oifantsfontein, Tembiso, Winnie Mandela }\end{array}$ & 311 & 179 \\
\hline & & & $\begin{array}{l}\text { Ekcurhuleni North 2: Bedfordview, Boksburg, Ohief } \\
\text { Albert Luthulli, Dan Kubheka, Edenvale, Endayenl, } \\
\text { Esangweni, triveleng, Kemston, Leehabong, Ramaphosa, } \\
\text { Reiger Park, Van Drk Park }\end{array}$ & 320 & 167 \\
\hline & & & $\begin{array}{l}\text { Ekurhuleni South 1: Aberton, Brackenhurst, Eden } \\
\text { Park, Primrose, Germiston, Leondale, Dawn Park, } \\
\text { Tswelopele, Yosloorus, Vill, Uiza }\end{array}$ & 213 & 103 \\
\hline & & & $\begin{array}{l}\text { Ekurhuleni South 2: Thokoza, Greenfields, Katiehong. } \\
\text { Moleleki, Zonkizizwe, Paim Ridge, Moleleki, } \\
\text { Tsietsi Sunrise View, Tamaho, Khumalo, Motsamai }\end{array}$ & 88 & 32 \\
\hline & & & Unallocated & 52 & 8 \\
\hline \multirow{4}{*}{ Sedibeng } & \multirow{4}{*}{127} & \multirow{4}{*}{37} & Lesedi & 14 & 5 \\
\hline & & & Emfuleni & 82 & 28 \\
\hline & & & Midvaal & 18 & 4 \\
\hline & & & Unallocated & 13 & \\
\hline \multirow{4}{*}{ West Rand } & \multirow{4}{*}{510} & \multirow{4}{*}{64} & Mogale City & 144 & 44 \\
\hline & & & Rand West City & 57 & 15 \\
\hline & & & Merafong City & 255 & 5 \\
\hline & & & Unallocated & 54 & \\
\hline Unallocated & 408 & & & & \\
\hline Total & 5626 & 2428 & & & \\
\hline Deaths & 47 & & & & \\
\hline
\end{tabular}




\begin{tabular}{|c|c|c|c|c|c|}
\hline District & $\begin{array}{l}\text { Total } \\
\text { District }\end{array}$ & $\begin{array}{l}\text { Total } \\
\text { Recoveries }\end{array}$ & Sub-District & $\begin{array}{l}\text { Total } \\
\text { Sub-District }\end{array}$ & $\begin{array}{l}\text { Recoveries } \\
\text { Sub-District }\end{array}$ \\
\hline \multirow{8}{*}{$\begin{array}{l}\text { City of } \\
\text { 3ohannesburg }\end{array}$} & \multirow{8}{*}{2732} & \multirow{8}{*}{1391} & $\begin{array}{l}\text { City of Johannesburg A: Diepsloot, Kya Sands, } \\
\text { Dainfern, Midrand, Lanseria, Founways, Ivory Park. }\end{array}$ & 284 & 218 \\
\hline & & & $\begin{array}{l}\text { City of Johannesburg B: Randburg, Rosebank, } \\
\text { Emmarentia, Greenside, Melville, Mayfair, Northcliff, } \\
\text { Parktown, Parktown North }\end{array}$ & 403 & 191 \\
\hline & & & $\begin{array}{l}\text { City of Johannesburg C: Roodepoort, Constantia Kloof, } \\
\text { Northgate, Florida, Bram Fishersville }\end{array}$ & 266 & 122 \\
\hline & & & $\begin{array}{l}\text { City of Johannesburg D: Doornkop, Soweto, } \\
\text { Dobsonville, Protea Glen }\end{array}$ & 452 & 180 \\
\hline & & & $\begin{array}{l}\text { City of Johannesburg E: Alexandra, Wynberg, } \\
\text { Sandton, Orange Grove, Houghton }\end{array}$ & 472 & 303 \\
\hline & & & City of Johannesburg F: Inner City, Johannesburg South & 542 & 194 \\
\hline & & & $\begin{array}{l}\text { City of Johannesburg G: Orange Farm, Weilers Farm, } \\
\text { Ennerdale, Lenasia, Eldorado Park, Protea South }\end{array}$ & 176 & 99 \\
\hline & & & Unallocated & 137 & 84 \\
\hline \multirow{8}{*}{ City of Tshwane } & \multirow{8}{*}{709} & \multirow{8}{*}{354} & $\begin{array}{l}\text { City of Tshwane 1: Ga-Ranicuwa, Mabopane Winterveldt, } \\
\text { Soshanguve, Rosslyn, Karenpark, Wonderboom, Akasia, } \\
\text { Nina Park, Orchads, Amandasig. Thereza Park, Pretoria } \\
\text { North }\end{array}$ & 95 & 58 \\
\hline & & & $\begin{array}{l}\text { City of Tshwane 2: Hammanskraal, Temba, Suurman, } \\
\text { Dilopye, Stinkwater, Ramotse, New Eesterus, } \\
\text { Kameeldrit, Pyramid/Rooiwal, Doornpoort, Kekana } \\
\text { Gardens, KekansStad, Marokolong, Randstown, Kanana }\end{array}$ & 41 & 15 \\
\hline & & & $\begin{array}{l}\text { City of Tshwane 3: Atteridgeville, Laudium, Pretoria CBD, } \\
\text { Hercules, Danville, Saulsville, Lotus, Pretoria West }\end{array}$ & 238 & 105 \\
\hline & & & $\begin{array}{l}\text { City of Tshwane 4: Lyttelton, Eldoraigne, Waterkloof, } \\
\text { Olievenhoutbosch, Rooihuiskraal, Lyttelton, Silverton, } \\
\text { Centurion, Brooklyn, Hatfield }\end{array}$ & 153 & 70 \\
\hline & & & $\begin{array}{l}\text { City of Tshwane 5: East Lynne, Rayton, Cullinan, } \\
\text { Dewagensdrift, Refilwe, Silverton, Onverwacht }\end{array}$ & 22 & 11 \\
\hline & & & $\begin{array}{l}\text { City of Tshwane 6: Eesterus, Lethabong, Mamelodi, } \\
\text { Silverlakes, Garsfontein, Lynnwood, Queenswood, } \\
\text { Wilgers, Watloo, Equestria, Mooikloof, Brummeria }\end{array}$ & 118 & 76 \\
\hline & & & $\begin{array}{l}\text { City of Tshwane 7: Ekangala, Sokhulumi, Dark } \\
\text { City, Zithobeni, Bronkhorstspruit, Kanana, } \\
\text { Rethabiseng }\end{array}$ & 19 & 12 \\
\hline & & & Unallocated & 23 & 7 \\
\hline \multirow{7}{*}{ City of Ekurhuleni } & \multirow{7}{*}{1140} & \multirow{7}{*}{582} & $\begin{array}{l}\text { Ekurhuleni East 1: Etwatwa, Daveyton, Brakpan, } \\
\text { Tsakane }\end{array}$ & 84 & 56 \\
\hline & & & Ekurhuleni East 2: Springs, Kwa-Thema, Duduza, Nigel & 72 & 37 \\
\hline & & & $\begin{array}{l}\text { Ekurhuleni North1: Birchleigh, Birchleigh North, } \\
\text { Bonaero Park, Crystal Park, Erin, Ethafeni, Kempton } \\
\text { Park, Olifantsfontein, Tembisa, Winnie Mandela }\end{array}$ & 311 & 179 \\
\hline & & & $\begin{array}{l}\text { Ekurhuleni North 2: Bedfordview, Boksburg, Chief } \\
\text { Albert Luthuli, Dan Kubheka, Edenvale, Endayeni, } \\
\text { Esangweni, Itireleng, Kemston, Lethabong, Ramaphosa, } \\
\text { Reiger Park, Van Dyk Park }\end{array}$ & 320 & 167 \\
\hline & & & $\begin{array}{l}\text { Ekurhuleni South 1: Alberton, Brackenhurst, Eden } \\
\text { Park, Primrose, Germiston, Leondale, Dawn Park, } \\
\text { Tswelopele, Vosloorus, Villa Liza }\end{array}$ & 213 & 103 \\
\hline & & & $\begin{array}{l}\text { Ekurhuleni South 2: Thokoza, Greenfields, Katlehong, } \\
\text { Moleleki, Zonkizizwe, Palm Ridge, Moleleki, } \\
\text { Tsietsi Sunrise View, Tamaho, Khumalo, Motsamai }\end{array}$ & 88 & 32 \\
\hline & & & Unallocated & 52 & 8 \\
\hline \multirow{4}{*}{ Sedibeng } & \multirow{4}{*}{127} & \multirow{4}{*}{37} & Lesedi & 14 & 5 \\
\hline & & & Emfuleni & 82 & 28 \\
\hline & & & Midvaal & 18 & 4 \\
\hline & & & Unallocated & 13 & \\
\hline \multirow{4}{*}{ West Rand } & \multirow{4}{*}{$\mathbf{5 1 0}$} & \multirow{4}{*}{64} & Mogale City & 144 & 44 \\
\hline & & & Rand West City & 57 & 15 \\
\hline & & & Merafong City & 255 & 5 \\
\hline & & & Unallocated & 54 & \\
\hline Unallocated & 408 & & & & \\
\hline Total & 5626 & 2428 & & & \\
\hline Deaths & 47 & & & & \\
\hline
\end{tabular}

GAUTENG

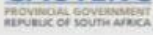

Gauteng Health @GautengHealth \#COVID-19 \#GautengCOVID19 https://twitter.com/GautengHealth/status/1269559311988150274 
The Western Cape Department of Health received a clean audit for the 2018/2019 financial year in consolidated audit results released by the country's Auditor General. It was achieved for the first time in the history of the sector and the report attributed it to implementation of action plan, established procedures and policies and effective leadership culture (AGSA 2019).

Such an achievement, however, does not change a few realities, as the Western Cape for over a decade attracts substantial number of internal and foreign migrants, the vast majority of whom are poor and unemployed, seeking a better future for their families. Migration in all its aspects is a key demographic process as it changes several social realities at all levels of life, such as age distribution, employment and the labour market, leisure, and crime tendencies. Statistics South Africa estimated that for the period 2016-2021, the Western Cape experienced an influx of 311004 immigrants, the second highest after Gauteng that attracted 1048440 (Statistics South Africa 2018a). Of the Western Cape immigrants, 140000 were from the Eastern Cape, the vast majority looking for employment and a better life. The Eastern Cape has remained for many reasons a predominantly rural district, with limited job opportunities (Personal Interview 3, Economist and Consultant, Eastern Cape). Both external and internal migration in South Africa, especially the latter, are not recent phenomena, especially after 1994, as internal migration in the country has become an act and movement of sheer necessity, a search for a job, better educational opportunities at all levels, and better health (Personal Interview 4, Senior Researcher, Labour and Geography, Western Cape).

In this context, the emigration of Eastern Cape residents to Western Cape is one of the reasons that has made the latter the receiver of most immigrants in South Africa, according to the latest statistics (Statistics South Africa 2018 b; The South African 2018). Another reason for mass migration from the Eastern Cape is the belief or general perception that the province and its political and administrative leadership have a strong tendency to corruption. Given the scientific predictions by top medical scientists indicating that even though at present the Western Cape tops the death list, it was expected that both the Eastern Cape and Gauteng would be facing major waves of infections soon. It was felt that an exploration of the Eastern Cape's Health Department's historical and present background and the corruption effects on the poor and the vulnerable, would make the connection a thoughtful experience.

During the first 15 years of the new millennium, the Eastern Cape Department of Health was a terrain of multiple corruption, clientism, nepotism, 
fraud at all operational levels and sections. In preliminary forensic investigations that lasted a few years and undertaken by the Eastern Cape Provincial Health Department, the SIU (Special Investigating Unit), (SIU), Asset Forfeiture Unit and the SA Revenue Service, evidence emerged that 8034 employees of the Provincial Department of Health were directors of active companies for years. It was reported that 929 of them were listed as suppliers for the Health Department. In addition, 235 of those 8034 members had received payments of R42.8 million from the department that included R7.3 million for the provision of medical support staff, R3.8 million for an emergency services staff member, and R 3.5 million and R4 million for engineering support staff. At another level, it was suspected that 544 departmental workers were ghost employees after it was established that they had produced invalid identity numbers, while it was also discovered that there were 35 spouses of departmental employees involved through their links with 35 companies, which throughout that period had received payments of R11 million. (Van Rooyen 2013). On this case alone, the amount mentioned in the preliminary report was R1.4 million. However, corroborated interviews with two civil servants in the province indicated that on the $4^{\text {th }}$ of February 2013, The Times newspaper reported that a leaked document in its Editor's possession indicated that as many as 23221 of the health department's 56000 employees were directly involved in providing direct services to the Department as well as goods (Personal Interviews 5 and 6, Middle Managers, Eastern Cape). In the same Report, the Department of Health denied these specific allegations, confessing that only about 9000 employees were listed on their supplier database, a fifth of all employees (Personal Interviews 5 and 6; Van Rooyen 2013).

In one of what has been described by a number of those present preChristmas 'anti-corruption meetings' organised by the then leadership of the Health Department in December 2012, and attended by over 150 senior officials in capital Bhisho, a forensic investigation undertaken by Price Waterhouse Coopers pointed to a senior accountant that had been awarded 13 contracts to companies owned by her sister-in-law, sisters, a niece and her husband, worth R4 million, while she kept all these transactions meticulously in her professional diary. These contracts were guaranteed especially during the period between 2008 and 2009, as the senior accountant colluded with at least 5 managers in the financial and internal audit departments. Such issues of hard-core corruption and fraud led to over 1000 staff dismissals or cases where people were 'encouraged to resign' in the three years between 2010 and 2013, 
including the Superintendent General of the Department, who was the senior manager leading the anti-corruption fight (Personal Interview 7, Retired Senior Manager, Eastern Cape).

The Times Live February article produced an official document which showed that a former Chief Financial Officer siphoned off almost R7-million in payments to close relatives after a senior manager of the Department took it upon himself to follow paper trails and official documents while scrutinising existing and past relationships amongst employees and service providers. It was discovered that 1939 suppliers of medical equipment and service providers possessed more than one bank account, a fact that enabled them to receive duplicate payments for the same product or service a fact that ultimately led to a R300-million theft. Over the years, stamped and approved blank invoices from departmental officials allowed companies including bogus ones, to fill in amounts for payments which they thought could be acceptable and paid up. Over the years, the CFO's husband's payments included R1.3 million for stationary and paid more than R3-million to her daughter's catering company, in 230 payments, most of them between 2007 and 2010. She was fired for gross misconduct in 2011 after a disciplinary hearing. She lost a Labour Court case, an arbitration hearing that her ruled the dismissal was fair (Child 2013; Personal Interviews 5 and 6).

For several years, it was a well-kept secret in the whole province that the Eastern Cape Health Department was diverting money away from hospitals including Cecilia Makiwane Hospital, a case that was investigated by the Hawks. The Hawks were seeking evidence of fraudulent pay-outs of more than R110-million by the department, which were re-directed to the pockets of senior ANC officials in the province. This even though a whistle blower provided evidence that the Department paid the Coega Development Corporation (CDC) R111-million in management fees. This payment was done without invoices or service-level agreement. Several ANC legislature members and senior party politicians convinced the Department to pay Coega, a stateowned entity, this massive amount (Personal Interview 8, Senior Journalist and NGO Board Member, Western and Eastern Cape).

The funds were diverted from the 38 urgent hospital projects for the 2018-2019 financial year. This was done even though the payment was irregular and a portion of a R150 million arbitration award, following a battle between the Eastern Cape Department of Health and the entity. The massive payment was challenged in an internal arbitration that found the payment 
legitimate because there was no real objection to the issue on the part of the Department of Health regarding the method or value that determined the amounts in dispute. Despite been approached to deal with the issue both the Hawks and the SIU did not respond (Jika 2019; Personal Interview 9, Senior Civil Servant, Gauteng; Interview No 4).

Interestingly, the senior manager responsible for technical and infrastructure management, who exposed the details of the above, had his services terminated three months before the tribunal, after he had prepared the documents exposing the issues and deals between Coega and the Department of Health. In his internal inquiry, he was charged with misconduct for contravening provisions and a few other relevant prescripts in the senior management handbook (RSA 2020; Personal Interviews 5 and 7). Because of these realities, the research of a renowned investigator of public service in the province showed conclusively that in 2012, 17 hospitals and 168 clinics lacked piped water; $68 \%$ of hospitals lacked essential medical equipment; $16 \%$ of the facilities had no telephones and were accessible by road only under good weather conditions; 42 health facilities operated only via generators as they had no proper electricity, and their staff vacancy rates stood at $46 \%$ (mostly clinical posts), meaning that in order to be filled, an additional $\mathrm{R} 9$ billion was needed (Bateman 2012).

Additional specialised empirical research in the province during the same period pinpointed the proliferation of duplicate payments to single companies. A forensic investigation indicated that duplicate payments amounting to R34, 109,375.56 were found. In addition, tender fraud became a norm and the most expensive act of corruption and fraud. It took place in a wide variety of ways, such as the case of tenders by 'multiple' supplier companies owned by the same individual(s) or the officials authoring the tender specifications also benefitting from the tender award. On many occasions, both fraudulent practices occurred in one tender. At another level of corruption, a 'skills audit' discovered that 10,221 employees of the department's 47,000 were receiving government grants illegally (Personal Interview 11, Forensic Accountant, NGO, Western Cape). All these corrupt acts led to the reality of 'one doctor for 120,000 people' as in the case of Madwaleni Hospital, a previously well-run 180-bed hospital in the rural Eastern Cape, with much highly acknowledged success until 2009. By 2012, the area's population of 120000 was serviced by one medical practitioner. The hospital's organogram showed that there should be 14 . The funds had run out. These 13 posts could not be 
filled as the national Department had placed a moratorium on appointing new critical staff in the Eastern Cape public health system (Kardas-Nelson 2012).

The historical periodization of several corrupt acts in the Department has led to the present situation where there is common belief that the provincial government is hiding important information from the people. It is common knowledge that there were no coronavirus cases in the province in the first four weeks of the lockdown, but while the beginning of Level 4 phase began, the virus had spread in both urban and rural communities. Following a visit by the Minister of Health to the province and the arrival of senior officials and 10 epidemiologists, a quarantine facility was set up in a guesthouse in Cala, a deep rural area. The facility was shut down in two days following community protests and the patients were moved to a hospital, while the government announced that the names and addresses of 120 quarantine guest houses would not be revealed in order to protect the virus victims (Majavu 2020).

While these events were unfolding, it was revealed that continued corruption including the revelation that the private guesthouses used to accommodate Health Department employees for over a year, were owned by politically connected business people; this forced the new Premier to announce a forensic investigation. The Transport Department was also under the spotlight for illegal procurement of sanitisers, having paid R47 million for footbridges that have not been built yet (Personal Interview 12, NGO and CBO researcher, Eastern Cape). The provincial government and the Department of Health have also faced serious problems because of their relations with community care workers and primary healthcare nurses who trace and treat patients who have Covid-19, as several still operate on one-year fixed term contracts without benefits since 1992, earning a R3500 stipend per month. All primary healthcare nurses were demoted to a lower stipend scale in 2012, following their transfer from the municipalities to the Health Department.

There have been perpetual strikes by doctors, nurses and health workers at provincial hospitals in Libode (St Barnabas) and Cacadu (Glen Grey), because of shortage of PPE (personal protective equipment), including masks, gowns, gloves and hair nets, while it has been reported that in the Livingstone Hospital in Port Elizabeth, staff had to re-use PPEs as all washing machines were not operational. While these realities continued to emerge, the procurement process for the purchase of such equipment unfolded slowly, paying attention to detail while a temporary hospital was opened in Port Elizabeth and two quarantine sites were established in the Port Elizabeth and 
East London stadiums. The question is how these realities can really affect the poor and vulnerable who, despite the increases received by the government in its effort to adhere to the Constitutional rights associated with the provision of access to sufficient food, healthcare services and relief from economic hardship, still suffer.

The situation in relation to fundamental healthcare services for the poor in the Eastern Cape and its relation to corruption has been touched upon. The financial incentives and economic measures put in place by the government need to be examined in the context of the existing financial realities during the period under investigation and the repercussions for the poor and vulnerable communities. The first issue at hand is the harsh reality facing millions of people who have lost jobs, and have not been able to earn an everyday living in the informal sector. As shown earlier, more than half of the country's population lives below the poverty line of R1267 per month, as identified by Statistics South Africa. They were allocated a tenth of the R500 million 'economic relief package'.

A combined University of Johannesburg and Human Sciences Research Council coronavirus impact survey indicated that hunger had become a seriously pressing issue during the lockdown period, as $28 \%$ of survey participants indicated they had gone to bed hungry since March the $26^{\text {th }}$, while $18 \%$ indicated that someone else in household had the same experience (UJ 2020). Serious questions arose because of the delay of more than five weeks from the $26^{\text {th }}$ of March regarding the child support grant increase, as the delay significantly affected the most vulnerable social groups amongst the poor. The promised extra R500 from June to October is an increase for the caregiver and the child, meaning more hunger for millions of children as the closing of schools denotes that there will be no learners' feeding schemes. The caregivers' lack of eligibility for the coronavirus grant and food parcels leads to more hunger for children and families.

The unemployment grant of R20-billion over six months is basically intended for individuals without access to social grants or UIF payments. Given the fact that the prospective receivers are obligated to produce proof of residence, banking details, and identity documents, it becomes obvious that the millions in the urban informal settlements and the rural areas, have almost no chance of qualifying. The 'universal grant' of R350 is lower than the children's grant. Research by the Pietermaritzburg Economic Justice and Dignity Group collected information on food prices in Pietermaritzburg supermarkets which 
target the low-income market on the 23 April and compared these prices to those which were collected from the same establishments on the $2^{\text {nd }}$ of May (4 days before the lockdown begun). It was found that the cost of the household food basket had increased by R65,67 (1.9\%) to R3,473.75 over the first three weeks of the lockdown. However, when comparing to prices before the lockdown started (2 March - 23 April), the cost of the household food basket increased by R252.75 (7.8\%) from R3,221 to R3,473.75. (Pietermaritzburg Economic Justice and Dignity Group 2020). As one of the interviewees mentioned:

For us there have been questions that have not been answered yet and they will be never answered because they are either serious or they cannot be answered: Who were the beneficiaries of the R500 billion and the R130 billion from the budget reprioritisation what was the exact cost of the 200 Cuban medical doctors in the end of their mission? What really happened to the perpetual immunity of these politicians and administrators who loot the food parcels throughout the country? All these things were in the newspapers. What about the eThekwini blankets tender? When the SIU announced publicly that they will fight crime and corruption, no one saw them nowhere; they forgot about the drug dealers, the fake cigarette gangsters, the police people stealing. Yes, it was good they increased the money for those who get the social grants, but do they know that food prices have gone up by 40 per cent? Look at the petrol price, look at the municipal rates increases for those who pay them ... then eThekwini spends millions to security companies to chase away Abahlali. The poor are poorer and they starve from a week before the $26^{\text {th }}$ till now. If it was not for the NGOs, the CBOs and those who care, more would have died from starvation. Corruption, greed, poverty, coronavirus, immunity for the crooks, the thieves, the conmen (Personal Interview 10, NGO Board Member, Analyst, KwaZulu-Natal).

\section{Conclusion}

There is no doubt that the coronavirus pandemic is a major challenge as the whole world is still in anticipation of the height of the outbreak. There have been international examples showing that it takes such a major and frightening 
challenge for a country, a region or even a Continent, to upgrade and develop new visions and realities for peoples' health. This is in fact what took place after the experience of the Ebola outbreaks in West Africa, when the attempts in improving health care infrastructure, systems, and processes, produced results. The reality is founded in the effort to plan, design, and implement initiatives that when achieved, are governed by intensive scrutiny, and further mobilisation of resources that are dedicated towards strengthening and cementing solid health system. This means that outbreaks need to be not only a memory of struggle and death, but also an opportunity to create a space for more research, communication, debate, open, frank and truthful discussions on a matter of life and death. In that spirit, the most important success factor is convincing the state and its institutions to act honestly, transparently and with accountability as the foundations of efficiency and effectiveness.

These are fundamental priorities because corruption is the weakest link in the effort to strengthen the hourly functionality of health systems, which unfortunately become weaker during a pandemic despite the heroic performance of the vast majority of medical, nursing and helping staff at all levels. These are facts that need deep thinking and action because during an outbreak, in most cases the corrupt individuals, groups, and syndicates in all walks of life become so operational that they exacerbate fear, uncertainty, disruption, distractions and even death.

Corruption hampers the governments' response to such a major crisis. The corrupt degrade the quality of service provision sapping healthcare systems. Care providers are turned into day sufferers because of the lack of EPPs and the ever-increasing number of sick patients who are sent back because of the lack of beds, pharmaceuticals, and water. Corruption erodes public trust in government; it is instrumental, during the pandemic, in closing provincial hospitals, undermines social cohesion, and in making supermarket oligopolies richer.

\section{References}

AGSA 2019 PFMA Reports 2018/2019. Available at:

https://www.agsa.co.za/Reporting/PFMAReports/PFMA2018-2019.aspx (Accessed on 8 November 2019.)

Barr, A., M.P. Lindelow \& P. Serneels 2009. Corruption in Public Service 
Delivery: An Experimental Analysis. Journal of Economic Behaviour \& Organization 72,1: 225 - 39.

https://doi.org/10.1016/j.jebo.2009.07.006

Bateman, C. 2012. 'Will our public healthcare sector fail the NHI?' South African Medical Journal 102,11: 817-817.

https://doi.org/10.7196/SAMJ.6358

PMid:23281549

Fulela, B. 2008. Checking the Post: Derrida and the Apartheid Debate. Alternation 15,2: 11 - 37.

BusinessTech 2020. Here is How the Average Price for a Household Food Basket has Increased in South Africa. Available at:

https://businesstech.co.za/news/finance/399071/heres-how-the-averageprice-for-a-household-food-basket-has-increased-in-south-africa/ (Accessed on 30 June 2020).

Child, K. 2013. Fraudsters' paradise, Times Live 04 February. Available at: https://www.timeslive.co.za/news/south-africa/2013-02-04-fraudstersparadise/ (Accessed on 17 June 2020). City Press 2020. Covid -19 Big Wave Coming, 07 June 2020. Alves Galvão, M.G., M. Rocha Crispino Santos \& A.J.L. Alves da Cunha 2014. Amantadine and Rimantadine to Prevent and Treat Influenza $A$ in Children and the Elderly. Cochrane. November 14. Available at: https://www.cochrane.org/CD002745/ARI_amantadine-and-

rimantadine-to-prevent-and-treat-influenza-a-in-children-and-the-

elderly. (Accessed on 18 July 2018.)

Greer, S., M. Wismar \& J. Figueras 2016. European Observatory on Health Systems and Policies Series. Strengthening Health System Governance: Better Policies, Stronger Performance. New York: McGraw-Hill Education.

IFRC 2014. Fraud in Ebola Operations. Available at:

https://media.ifrc.org/ifrc/ifrc-statement-fraud-ebola-operations/ (Accessed on 18 July 2018.)

Jika, T. 2019. Hawks Probe R111m Hospital Fraud. Mail and Guardian, April 18. Available at: https://mg.co.za/article/2019-04-18-00-hawks-prober111m-hospital-fraud/ (Accessed on 22 May 2019.)

Kardas-Nelson, M. 2012. Corruption in the Eastern Cape. Available at: https://www.spotlightnsp.co.za/2012/12/05/corruption-in-the-easterncape/ (Accessed on March 15 2014.) 
Mantzaris, E.A. 2018. Towards an Evidence-Based Corruption Index in South Africa: The First Step. African Journal of Public Affairs 10,4: 271 - 294. Majavu, A. 2020. Will the Eastern Cape Pass the Covid-19 Test? New Frame May 7. Available at: https://www.newframe.com/will-the-eastern-capepass-the-covid-19-test/ (Accessed on 17 June 2020.)

Pietermaritzburg Economic Justice \& Dignity Group 2019. Household Affordability Index, September. Available at: https://pmbejd.org.za/wpcontent/uploads/2019/09/September-2019-Household-AffordabilityIndex-PMBEJD.pdf (Accessed on 29 November 2019.)

Pillay, P. \& E.A. Mantzaris 2017. Corruption in the Health Sector in South Africa and India: Some Considerations and Reflections. African Journal of Public Affairs 9,8: 49 - 61.

Presidency of South Africa 2020. From the Desk of the President, June 8. Available at:

https://twitter.com/PresidencyZA/status/1269861536316735489

(Accessed on 17 June 2020).

RSA 2020. EC Health Department Terminates Service of General Manager for Infrastructure Programme Following Disciplinary Case Guilty Finding. Available at:

https://www.gov.za/speeches/eastern-cape-health-terminates-servicegeneral-manager-infrastructure-programme-7-mar-2019 (Accessed on 17 June 2020.)

Statistics South Africa 2018b. Statistical Release P030 Mid-year Population Estimates 2018. Available at:

http://www.statssa.gov.za/publications/P0302/P03022018.pdf (Accessed on 17 June 2020.)

The South African 2018. StatsSA Report: Eastern Cape Still Holds the Record for Out-migration. Available at:

https://www.thesouthafrican.com/news/stats-sa-report-eastern-cape-stillholds-the-record-for-out-migration/ (Accessed on 17 June 2020.)

Stats South Africa 2019a. Statistical Release P0310. 1 National Poverty Lines 2019 Statistical Release. Available at:

http://www.statssa.gov.za/publications/P03101/P031012019.pdf (Accessed on 17 June 2020).

Statistics South Africa 2019b. General Household Survey. Available at: http://www.statssa.gov.za/?page_id=1854\&PPN=P0318\&SCH=7652. (Accessed on 17 June 2020). 
UJ Coronavirus Impact Survey Summary Findings 20 April 2020. Available: https://www.uj.ac.za/newandevents/Documents/UJ\%20HSRC\%20summ ary\%20report\%20v1.pdf (Accessed on 17 June 2020.)

U4 BRIEF 2015. Ebola and Corruption: Overcoming Critical Governance Challenges in a Crisis Situation. March. Available at:

https://www.cmi.no/publications/file/5522-ebola-and-corruption.pdf (Accessed on 22 May 2015.)

Van Rooyen, P. 2013. Fraud Corruption in Eastern Cape Department of Health Leadership. 05 February. Available at:

http://www.leadershiponline.co.za/articles/fraud-corruption-in-easterncape-department-of-health-4439.html (Accessed on 16 May 2015.)

Vian, T. 2008. Review of Corruption in the Health Sector: Theory, Methods and Interventions. Health Policy and Planning 23: 83 - 94.

https://doi.org/10.1093/heapol/czm048

PMid: 18281310

WHO 2000. World Health Report 2000: Health Systems: Improving Performance. Geneva: World Health Organization.

WHO 2012. Everybody's Business. Strengthening Health Systems to Improve Health Outcomes: WHO's Framework for Action. Geneva: World Health Organization.

Evangelos A. Mantzaris Retired Professor Mangosuthu University of Technology mantzar@sociologist.com

Pregala Pillay Professor

School of Public Leadership University of Stellenbosch pregala.pillay@spl.sun.ac.za 